Agro Ekonomi Vol. 27/No. 2, Desember 2016

\title{
PERSEPSI PENDAMPING TERHADAP PELAKSANAAN PROGRAM UPSUS PAJALE DI DAERAH ISTIMEWA YOGYAKARTA
}

\section{The Perception of Program Adviser to Special Effort on Food Production of Paddy, Corn and Soybean in Yogyakarta Special District}

\author{
Urfan Faridhavin ${ }^{1}$, Roso Witjaksono ${ }^{2}$, Harsoyo $^{2}$ \\ ${ }^{1}$ Kementerian Pemberdayaan Perempuan dan Perlindungan Anak, \\ Jl. Medan Merdeka Barat No.15, Jakarta Pusat \\ ${ }^{2}$ Fakultas Pertanian Universitas Gadjah Mada \\ Jl. Flora, Bulaksumur, Yogyakarta 55281 \\ urfanfaridhavin@gmail.com
}

Diterima tanggal : 18 September 2016 ; Disetujui tanggal : 20 Oktober 2016

\begin{abstract}
In an effort to realize food security, the Ministry of Agriculture made a policy of agricultural development by preparing food self-sufficiency program embodied with Special Effort of Increasing Productivity of Rice, Corn and Soy (UPSUS PAJALE). This escort and assistance is conducted by Agricultural Extension (PNS and THL), BABINSA (Bintara Pembina Desa) and students. This research aim to know 1) the implementation of UPSUS PAJALE program in Yogyakarta Special District; 2) the perception rate of program adviser to implementation of UPSUS PAJALE program; and 3) the factors which affect to the perception of program adviser. The research used descriptive method. The sampling of location was chosen purposively, while the sampling of program adviser was taken by simple random sampling and total sample is 40 respondents. The data were analyzed with proportion test and multiple linier regression. The research results showed that the rate of program adviser perception to implementation UPSUS PAJALE program was in good category. Knowledge of program adviser positively affect to the perception. Factors that did not significantly influence to perception of program adviser were experience, motivation to work in agriculture, interaction with farmers, interaction with agricultural extention worker, and interaction with BABINSA (TNI).
\end{abstract}

Keywords : a program adviser, Perception, UPSUS PAJALE Program, Yogyakarta Special District

\section{INTISARI}

Dalam upaya mewujudkan ketahanan pangan, Kementerian Pertanian membuat kebijakan pembangunan pertanian dengan menyusun program Swasembada Pangan yang diwujudkan dengan program Upaya Khusus Peningkatan Produktivitas Padi, Jagung dan Kedelai (UPSUS PAJALE). Pengawalan dan pendampingan ini dilakukan oleh Penyuluh Pertanian (PNS maupun THL), BABINSA (Bintara Pembina Desa) dan mahasiswa.Penelitian ini bertujuan untuk 1) Mengetahui pelaksanaan program UPSUS PAJALE di DIY;2) Mengetahui persepsi pendamping terhadap pelaksanaan program UPSUS PAJALE; dan 3) Mengetahui faktorfaktor yang mempengaruhi persepsi pendamping terhadap pelaksanaan program UPSUS PAJALE. Metode penelitian yang digunakan adalah metode deskriptif. Pengambilan 
sampel lokasi dilakukan dengan metode purposif, sedangkan pengambilan sampel pendamping dengan metode acak sederhana dengan jumlah 40 responden pendamping UPSUS PAJALE di DIY. Data penelitian dianalisis menggunakan uji proporsi dan analisis regresi linier berganda. Hasil penelitian menunjukkan bahwa persepsi pendamping terhadap pelaksanaan program UPSUS PAJALE di DIY termasuk dalam kategori baik. Pengetahuan dari pendamping berpengaruh positif terhadap persepsi pendamping terhadap pelaksanaan program UPSUS PAJALE di DIY. Faktor yang tidak berpengaruh nyata terhadap persepsi pendamping tersebut adalah pengalaman, minat bekerja di bidang pertanian, hubungan dengan petani, hubungan dengan penyuluh pertanian serta hubungan dengan BABINSA.

Kata kunci: Daerah Istimewa Yogyakarta, Pendamping,Persepsi, Program UPSUS PAJALE

\section{PENDAHULUAN}

Dalam upaya mewujudkan ketahanan pangan, Kementerian Pertanian membuat kebijakan pembangunan pertanian dengan menyusun program Swasembada Pangan yang diwujudkan dengan program Upaya Khusus Peningkatan Produktivitas Padi, Jagung dan Kedelai (UPSUS PAJALE) yang diharapkan dapat dicapai pada tahun 2017, dengan target produksi tahun 2015 untuk padi sebesar 73,4 juta ton, produksi jagung sebanyak 20,3 juta ton dan kedelai menghasilkan 1,2 juta ton. Target produksi tersebut akan dapat dicapai dengan berbagai kegiatan antara lain : rehabilitasi jaringan irigasi tersier, penyediaan alat dan mesin pertanian, penggunaan benih unggul, penyediaan dan penggunaan pupuk berimbang, pengaturan musim tanam dengan menggunakan kalender musim tanam, dan pelaksanaan program GP-PTT (Gerakan Penerapan Pengelolaan Tanaman Terpadu) (BPPSDM Pertanian, 2015).

Pemenuhan swasembada pangan dipengaruhi oleh beberapa faktor, misalnya kompetensi dan keterampilan petani, sarana dan prasarana kegiatan bertani, bibit, pupuk, dan lain-lain. Hal yang berpengaruh juga adalah pendampingan dan pengawalan pelaksanaan program. Pengawalan dan pendampingan ini dilakukan oleh Penyuluh Pertanian (PNS maupun THL), BABINSA (Bintara Pembina Desa) dan mahasiswa. Ketiganya merupakan penggerak bagi petani karena berperan sebagai komunikator, fasilitator, advisor, motivator, edukator, organisator dan dinamisator.

Mahasiswa disebut sebagai Agent of Changes, karena mempunyai peran vital dalam pembangunan negara. Dari tangan mahasiswa banyak tercipta inovasi yang mumpuni. Selain itu, ide yang diciptakan banyak membuat keberagaman kemajuan negara, baik dari bidang sarana dan prasarana pembangunan, teknologi informasi, dan lain sebagainya. Tanpa terkecuali dalam bidang pertanian, khususnya mahasiswa pertanian banyak melakukan penelitian mengenai perkembangan sistem pertanian saat ini yang dilakukan masyarakat. Selain itu, 
tidak hanya dibekali ilmu dari perkuliahan, mahasiswa pertanian juga diajarkan tentang pelaksanaan kegiatan pertanian yang dilakukan langsung oleh pelaku utama maupun pelaku usaha pertanian. Tidak hanya melakukan kegiatan bertani selayaknya petani, mahasiswa pertanian juga mendapatkan pengetahuan tentang budidaya pertanian yang baik, mulai dari pengolahan lahan, penanaman, perawatan, sampai pada panen dan penanganan pasca panen. Terlebih lagi, mahasiswa pertanian juga dapat berdiskusi dengan petani tentang menghitung bagaimana kesejahteraan hidup mereka dengan bertani, biaya produksi pertaniannya, sampai pada perhitungan untung/rugi dari hasil pertanian yang dilakukan petani tersebut. Dalam hal ini, mahasiswa pertanian dirangkul oleh pemerintah untuk melakukan pendampingan terhadap pelaksanaan program UPSUS PAJALE yang dilakukan dalam rangka upaya pencapaian swasembada pangan nasional. Selain itu, alumni dari mahasiswa pertanian juga dapat bergabung dalam pelaksanaan pendampingan program ini.

Pelaksanaan pendampingan ini tentunya dipengaruhi oleh bagaimana persepsi pendamping tanpa terkecuali mahasiswa pendamping. Persepsi merupakan proses yang terjadi di dalam diri seseorang terhadap adanya rangsangan kemudian terjadi proses penyariangan dan interpretasi ataupun penafsiran terhadap rangsangan tersebut. Dengan terciptanya suatu persepsi, maka akan berpengaruh langsung terhadap bagaimana pelaksanaan pendampingan program UPSUS PAJALE ini. Oleh karena itu, hal tersebut sangatlah menarik apabila dilakukan studi yang mendalam tentang persepsi pertanian terhadap pelaksanaan program UPSUS PAJALE khususnya di Daerah Istimewa Yogyakarta(DIY). Penelitian ini dilakukan di DIY karena kondisi masyarakat petani yang beragam di setiap wilayahnya serta adanya berbagai mahasiswa pertanian yang mendampingi kegiatan ini yang berasal dari beberapa Perguruan Tinggi Negeri/Swasta dengan latar belakang yang berbedabeda sehingga akan terdapat banyak variasi data yang dapat mewakili berbagai kondisi. Penelitian ini bertujuan untuk 1) Mengetahui pelaksanaan program UPSUS PAJALE di DIY; 2) Mengetahui persepsi pendamping terhadap pelaksanaan program UPSUS PAJALE; dan 3) Mengetahui faktor-faktor yang mempengaruhi persepsi pendamping terhadap pelaksanaan program UPSUS PAJALE.

\section{Swasembada Pangan}

Swasembada pangan nasional berarti kita mampu untuk mengadakan sendiri kebutuhan pangan dengan bermacammacam kegiatan yang sesuai diperlukan masyarakat Indonesia dengan kemampuan yang dimiliki. Laju pertumbuhan penduduk yang positif membuat Indonesia harus terus 
menerus memacu produksi bahan pangan terutama beras agar tetap memenuhi kebutuhan dasar masyarakat. Sementara fenomena banjir dan kekeringan yang semakin tidak terkendali dan tingginya laju konversi fungsi lahan sawah ke penggunaan yang lain di luar produksi beras akhir-akhir ini, mengisyaratkan bahwa resiko akan terjadinya kegagalan produksi beras di negeri ini telah semakin meningkat dari waktu ke waktu. Merosotnya kemampuan finansial pemerintah dalam melakukan rehabilitasi dan perluasan jaringan irigasi bahkan telah membuat kondisi resiko produksi semakin buruk. Sehingga, ke depan sangatlah mungkin terjadi pada suatu periode waktu tingkat produksi beras nasional jatuh pada level yang jauh di bawah target yang dibutuhkan untuk mencapai swasembada beras. Pada saat itu, Indonesia akan kekurangan beras dalam jutaan ton. Bagi Indonesia, ketahanan pangan nasional yang lestari bukan hanya swasembada beras, tetapi swasembada pangan.

Pencapaian swasembada pangan selama ini mengalami peningkatan dan penurunan. Produksi padi pada tahun 2010 sebesar 66,47 juta ton, mengalami penurunan produksi pada tahun 2011 menjadi 65,76 juta ton, pada tahun 2012 mencapai 69,06 juta ton dan tahun 2013 sebesar 70,87 juta ton. Pada tahun 2014 ditargetkan mencapai 76,57 juta ton. Target produksi tahun 2011-2012 sebesar
22 juta ton dan 24 juta ton hanya tercapai 17,64 juta ton dan 19,39 juta ton. Realisasi dilakukan melalui Road Map. Berdasarkan data ARAM-II tahun 2013 produksi jagung mencapai 18,51 juta ton atau $93,34 \%$ dari target 19,83 juta ton. Pada tahun 2014 ditargetkan mencapai 20,82 juta ton. Pencapaian produksi kedelai 2010-2012 jauh di bawah target yang telah ditetapkan pada RENSTRA Kementerian Pertanian 2010 - 2014. Rendahnya capaian produksi kedelai terutama disebabkan karena tidak tercapainya luas panen dan rendahnya produktivitas riil yang dicapai petani. Berdasarkan data ARAM-II tahun 2013 produksi kedelai mencapai 0,81 juta ton (54\% dari target 1,5 juta ton). Pada tahun 2014 produksi kedelai ditargetkan 1,5 juta ton (RKT Kementan, 2014).

\section{Program UPSUS PAJALE}

Pemerintah pusat melalui Kementerian Pertanian terus menggulirkan program UPSUS PAJALE. Dana 16,9 Triliun dari Anggaran Pembangunan Belanja Negara Perubahan (APBN) 2015 digunakan untuk meningkatkan jumlah produksi padi, jagung dan kedelai bagi setiap daerah. Bantuan tersebut disampaikan kepada para petani dalam bentuk bantuan benih, pupuk, alat dan mesin pertanian (ALSINTAN). Dalam program UPSUS PAJALE, kegiatan yang dilakukan tidak hanya pemberian bantuan saja, namun juga dilakukan perbaikan jaringan irigasi, sistem 
tanam serentak, pengendalian OPT serta penerapan inovasi teknologi melalui GPPTT, PAT (Perluasan Areal Tanam), dan optimasi lahan (BPPSDM Pertanian, 2015).

\section{Kegiatan Pendampingan UPSUS PAJALE}

Pengawalan dan pendampingan program ini dilakukan Penyuluh Pertanian, BABINSA, dan mahasiswa. Penyuluh Pertanian merupakan tenaga teknis yang bertempat di BP3K (Balai Penyuluhan Pertanian, Perkebunan, Perikanan dan Kehutanan) pada masing-masing kecamatan. Penyuluh Pertanian tersebut ada yang sudah menjadi penyuluh PNS maupun penyuluh THL. Dalam kegiatan pendampingan UPSUS PAJALE, tugas Penyuluh Pertanain adalah melaksanakan pengawalan dan pendampingan pelaksanaan GP-PTT, POL, RJIT (Rehabilitasi Jaringan Irigasi Tersier), dan PAT. Penyuluh Pertanian berperan penting dalam meningkatkan kemampuan kelembagaan petani (POKTAN, GAPOKTAN, P3A, dan GP3A) dan kelembagaan ekonomi petani. Mengembangakan jejaring dan kemitraan dengan pelaku usaha, dan melakukan identifikasi pendataan serta pelaporan teknis pelaksanaan kegiatan.

BABINSA TNI AD merupakan satuan teritorial TNI AD paling bawah, yang berhadapan paling langsung dengan masyarakat. BABINSA berada di bawah Komando Rayon Militer, bagian dari
Komando Distrik Militer dan Komando Resor Militer, yang menginduk pada Komando Daerah Militer. Seorang BABINSA memiliki wilayah operasi pada suatu desa. Dalam Program UPSUS PAJALE, tugas BABINSA adalah menggerakkan dan memotivasi petani untuk tanam serentak, perbaikan dan pemeliharaan jaringan irigasi, pengendalian OPT, panen dan distribusi bantuan.

Mahasiswa sebagai pendamping Penyuluh Pertanian juga bergabung dalam kegiatan pendampingan ini. mahasiswa tersebut merupakan mahasiswa yang masih aktif maupun alumni dari Fakultas Pertanian yang diajak kerjasama untuk mendampingi petani dalam pelaksanaan program UPSUS PAJALE. Mekanisme pendampingan yang dilakukan saat ini melibatkan 5 STPP (Sekolah Tinggi Penyuluhan Pertanian) dan 14 Universitas Negeri/Institut Pertanian Negeri. STPP yang terlibat adalah STPP Medan, STPP Bogor, STPP Magelang, STPP Malang, dan STPP Gowa. Sedangkan untuk PTN yang terlibat adalah Universitas Syah Kuala (Aceh), Universitas Sumatera Utara (Sumut), Universitas Andalas (Sumbar), Universitas Sriwijaya (Sumsel), Universitas Lampung (Unila), Institut Pertanian Bogor (Bogor), Universitas Gadjah Mada (Yogyakarta), Universitas Lambung Mangkurat (Kalsel), Universitas Tanjungpura (Kalbar), Universitas Brawijaya (Malang), Universitas Udayana 
(Bali), Universitas Mataram (NTB), Universitas Tadulako (Sulteng), dan Universitas Hasanuddin (Sulsel). Para mahasiswa kemudian akan disupervisi dosen yang umumnya memegang 5-10 mahasiswa (BPPSDM Pertanian, 2015). Hampir sama seperti para Penyuluh Pertanian, tugas mahasiswa pendamping adalah melaksanakan pengawalan dan pendampingan pelaksanaan GPPTT, POL, RJIT, dan PAT. Selain itu mahasiswa juga berperan memfasilitasi introduksi teknologi dari Perguruan Tinggi, mengembangkan jejaring dan kemitraan dengan pelaku usaha serta identifikasi pendataan dan pelaporan teknis pelaksanaan kegiatan.

\section{Kegiatan Penyuluhan dan Penerapan Teknologi UPSUS PAJALE}

Petani merupakan sasaran atau target dari adanya program UPSUS PAJALE ini. Kegiatan yang dilakukan oleh petani yaitu meliputi kegiatan penyuluhan yang dilakukan oleh Penyuluh Pertanian atau dengan pemdamping lain dan juga kegiatan penerapan teknologi yang tersusun dalam UPSUS PAJALE. Dalam pelaksanaannya, dapat dilihat dari bagaimana tingkat kehadiran petani, keaktifan petani mengikuti penyuluhan, pengetahuan dan pemahaman, sikap ataupun perilaku yang ditunjukkan petani dalam menerapkan inovasi teknologi yang ada di UPSUS PAJALE ini. Seperti penggunaan bibit unggul, penggunaan kalender musim tanam, pengaturan irigasi, pemupukan berimbang dan lain sebagainya.

Penyuluhan pertanian mempunyai peran untuk membantu petani agar dapat menolong dirinya untuk mengatasi permasalahan yang dihadapinya secara baik dan memuaskan sehingga meningkat derajat kehidupannya. Dengan demikian nilai penting yang dianut dalam penyuluhan adalah pemberdayaan sehingga terbentuk kemandirian petani ( Sadono, 2008).

Penyuluhan pertanian di harapkan dapat mengantar petani Indonesia berproduksi secara mandiri (tanpa subsidi atau dengan subsidi minimal) dan sekaligus membuat tingkat kesejahteraan petani meningkat dengan lebih nyata dalam konteks pembangunan nasional untuk mendukung swasembada pangan (Indraningsih, 2015).

\section{Persepsi}

Menurut Wahyuni (2008) dalam Bilondatu (2013) perception is process by which an individuals selects, organizers, and interpretsstimuli into the a meaningfull and coherent picture of the world.

Persepsi adalah penilaian terhadap objek atau stimulus yang diidentifikasi dengan menggunakan panca indera (Fitria, 2013). Masukan stimulus yang diterima oleh seseorang menjadi pedoman berpikir tentang suatu hal/objek. Semakin banyak stimulus yang masuk dan diterima oleh 
seseorang, maka akan semakin kuat otak seseorang tersebut untuk berpikir dan menghasilkan pandangan/persepsi. Namun bila hanya ada sedikit masukan stimulus, maka akan memperkecil kerja otak untuk memikirkan suatu objek sehingga nantinya akan tercipta persepsi yang tidak kuat, atau bisa dibilang dengan keraguan akan suatu hal.

Persepsi adalah proses dimana individu memilih, mengorganisasi, dan mengartikan masukan informasi untuk menciptakan suatu gambarang tentang kehidupan ( Saputro, 2013).

\section{Faktor - faktor yang Mempengaruhi Persepsi}

Menurut Batuadji, dkk (2009) persepsi individu dipengaruhi oleh hal- hal yang berasal dari dalam dirinya dan hal-hal yang berasal dari luar dirinya. Hal-hal yang berasal dari dalam diri individu meliputi faktor-faktor personal dan pengalaman individu di masa lalu, sedangkan hal-hal yang berasal dari luar diri individu meliputi faktor stimulus dan faktor lingkungan sosial.

Menurut Soekanto (1990) dalam Rudyanto (2015), terdapat beberapa faktor yang mempengaruhi persepsi yaitu faktor internal dan faktor eksternal. Faktor-faktor internal adalah (1) keturunan/hereditas, (2) kondisi dan tuntunan biologis/fisiologis, (3) kecerdasan/pendidikan, (4) proyeksi diri (asumsi tentang perilaku orang lain yang dikaitkan dengan nilai-nilai diri sendiri), (5) harapan terhadap objek, (6) efek halo (generalisasi sesuatu yang bersifat khusus), (7) sifat dan keyakinan keagamaan, (8) nilai-nilai individu yang dianut dan (9) pengetahuan dan pengalaman masa lalu tentang suatu objek. Faktor-faktor eksternal adalah (1) norma masyarakat, (2) adat istiadat, (3) konformitas (upaya penyesuaian diri terhadap tuntutan orang lain/tekanan sosial) dan (4) pengaruh lingkungan dalam hubungan sosial.

\section{METODE PENELITIAN}

Metode dasar yang digunakan dalam penelitian ini adalah metode analisis deskriptif. Menurut Surakhmad (1990) metode analisis deskriptif yaitu usaha untuk mengumpulkan dan menyususn suatu data, kemudian dilakukan analisis terhadap data tersebut dan ditampilkan untuk melukiskan keadaan yang ada.

Lokasi penelitian dilaksanakan di Daerah Istimewa Yogyakarta. Pemilihan lokasi dilakukan secara purposive sampling dengan mempertimbangkan kondisi pertanian yang beragam sehingga dapat mewakili berbagai kondisi yang dapat mendukung program UPSUS PAJALE. Selain itu, banyaknya mahasiswa pertanian yang kuliah di universitas-universitas baik negeri maupun swasta yang berada di DIY memperbanyak kesempatan untuk menjadi mahasiswa pendamping program UPSUS PAJALE. 
Penentuan populasi pendamping dilakukan dengan memilih sampel mahasiswa yang terlibat dalam pendampingan program UPSUS PAJALE di Wilayah DIY. Penentuan populasi ini menggunakan purposive sampling. Keseluruhan mahasiswa pendamping dari berbagai universitas di DIY akan digabung menjadi empat populasi yang dipisahkan berdasarkan lokasi pelaksanaan program UPSUS PAJALE di DIY (Bantul, Sleman, Gunungkidul dan Kulon Progo).

Pengambilan sampel pendamping dilakukan dengan metode simple random sampling, dimana sampel diambil secara acak dari keseluruhan mahasiswa pendamping program UPSUS PAJALE yang telah bagi menjadi empat populasi, kemudian diambil secara acak 10 responden dari masing-masing populasi sehingga mandapatkan total 40 responden.

Analisis data yang digunakan untuk mengidenfikasi persepsi pendamping terhadap pelaksanaan program UPSUS PAJALE di DIY menggunakan data kuantitatif. Teknis analisis kuantitatif untuk menguji tingkat persepsi menggunakan uji proporsi dan faktor-faktor yang mempengaruhi persepsi diuji dengan analisis regresi linear berganda.

\section{Pengujian Hipotesis Pertama}

Hipotesis pertama mengenai persepsi pendamping terhadap pelaksanaan program UPSUS PAJALE diuji dengan menggunakan uji proporsi. Adapun uji proporsi yang dilakukan adalah sebagai berikut:

Ho : $\mathrm{P} \leq 50 \%$

Ha : $\mathrm{P}>50 \%$

Ho : Diduga kurang dari sama dengan 50 $\%$ pendamping memiliki persepsi baik terhadap pelaksanaan program UPSUS PAJALE di DIY.

Ha : Diduga lebih dari $50 \%$ pendamping memiliki persepsi baik terhadap pelaksanaan program UPSUS PAJALE di DIY.

Tingkat signifikansi pada $\alpha=$ $5 \%(0,05)$ dengan pengujian dilakukan menggunakan rumus :

$$
Z_{\text {hitung }}=\frac{\frac{x}{n}-P o}{\sqrt{\frac{P o(1-P o)}{n}}}
$$

Keterangan :

$\mathrm{X} \quad$ : jumlah sampel yang memiliki persepsi baik

$\mathrm{N} \quad$ : jumlah keseluruhan sampel (40 mahasiswa)

Po : koefisien keyakinan (50 \%)

Kriteria pengujian

$\mathrm{Z}$ hitung $\leq \mathrm{Z}$ tabel maka Ho diterima, $\mathrm{Ha}$ ditolak

$\mathrm{Z}$ hitung $>\mathrm{Z}$ tabel maka Ho ditolak, Ha diterima 


\section{Pengujian Hipotesis Kedua}

Hipotesis kedua tentang faktor-faktor yang mempengaruhi persepsi pendamping program UPSUS PAJALE diuji dengan menggunakan analisis regresi linear berganda. Persamaannya adalah:

$\mathrm{Y}=\mathrm{A}+\mathrm{b}_{1} \cdot \mathrm{X}_{1}+\mathrm{b}_{2} \cdot \mathrm{X}_{2}+\mathrm{b}_{3} \cdot \mathrm{X}_{3}+\ldots \ldots+\mathrm{b}_{6} \cdot \mathrm{X}_{6}$

Keterangan :

Y : persepsi pendamping terhadap pelaksanaan program UPSUS PAJALE

A : bilangan konstanta

$\mathrm{b}_{1}-\mathrm{b}_{6}:$ koefisien regresi

$\mathrm{X}_{1}$ : pengetahuan

$\mathrm{X}_{2} \quad$ : pengalaman

$\mathrm{X}_{3} \quad$ : minat bekerja di bidang pertanian

$\mathrm{X}_{4} \quad$ : hubungan dengan petani

$X_{5} \quad$ : hubungan dengan penyuluh pertanian

$\mathrm{X}_{6} \quad$ : hubungan dengan BABINSA

Pengujian hipotesis :

Ho : Tidak ada pengaruh positif antara pengetahuan, pengalaman, minat bekerja di bidang pertanian, hubungan dengan petani, hubungan dengan Penyuluh Pertanian, dan hubungan dengan BABINSA dengan persepsi pendamping terhadap pelaksanaan program UPSUS PAJALE.

Ha : Ada pengaruh positif antara pengetahuan, pengalaman, minat bekerja di bidang pertanian hubungan dengan petani, hubungan dengan
Penyuluh Pertanian, dan hubungan dengan BABINSA dengan persepsi pendamping terhadap pelaksanaan program UPSUS PAJALE.

\section{HASIL DAN PEMBAHASAN}

Pelaksanaan Program UPSUS PAJALE di DIY

UPSUS PAJALE di DIY dilaksanakan pada 4 kabupaten yaitu Bantul, Sleman, Gunungkidul dan Kulon Progo. Dalam pelaksanaannya, UPSUS PAJALE melibatkan berbagai pihak mulai Penyuluh Pertanian, BABINSA serta mahasiswa yang ditugaskan untuk menjadi pendamping petani dalam menerapkan teknologi inovasi dari program ini. Penyuluh Pertanian bertugas untuk memberikan penyuluhan terkait hal-hal teknis dari persiapan, tanam, perawatan, panen dan pasca panen. Mahasiswa pendamping secara aktif mengikuti setiap kegiatan, membantu Penyuluh Pertanian melakukan pendampingan petani dan memberi dukungan dari analisa teknologi dan administrasi. Sedangkan BABINSA melakukan pengawasan dan mendorong petani melalui pengolahan tanah, tanam serentak, pengendalian hama terpadu, dan panen serentak. Kegiatan UPSUS PAJALE di DIY antara lain:

a. Bantuan RJIT diberikan kepada kelompok tani sebesar Rp. 25.000.000 dalam bentuk tunai untuk dibelanjakan material bangunan untuk membangun 
atau merehabilitasi jaringan irigasi.

Pembangunan maupun rehabilitasi tersebut dikerjakan oleh petani yang tergabung dalam kelompok tani tersebut. Bantuan tersebut diharapkan dapat memperlancar distribusi dan memenuhi pasokan air lahan pertanian.

b. Pemerintah memberikan bantuan Rice Milling Unit (mesin penggiling beras), Combine Harvester (mesin panen kombinasi), Corn Sealer (mesin pengupas jagung), Power Threaser (mesin penebah padi), pompa air dan traktor. Bantuan ALSINTAN tersebut didistribusikan di kecamatan dan diterima secara langsung oleh Gapoktan maupun Kelompok Tani.

c. Bantuan benih kepada petani diberikan melalui kelompok tani. Varietas benih padi yang diterima antara lain Situ Bagendit, Mekongga, IR 64, dan Inpari. Sedangkan jagung dan kedelai adalah benih hibrida. Setiap anggota kelompok tani menerima bantuan benih yang disesuaikan dengan luasan lahan. Setiap hektar luas tanam menerima benih sebanyak $25 \mathrm{~kg}$.

d. Kelompok tani mendapatkan bantuan pupuk urea dan NPK sesuai luasan areal pertaniannya. Pupuk yang diterima oleh kelompok tani selanjutnya didistribusikan kepada anggota kelompok tani. e. Pengaturan musim tanam dengan menggunakan KATAM yang berisikan informasi terkait prediksi musim, awal tanam, pola tanam, luas lahan potensial, wilayah rawan banjir maupun kekeringan, potensi serangan OPT, rekomendasi pemupukan, serta rekomendasi varietas. Adanya KATAM untuk setiap kecamatan, petani diharapkan dapat menentukan waktu tanam terbaik dan sekaligus menetapkan varietas yang sesuai, dan pemupukan yang rasional.

f. GP-PTT dilaksanakan pada bulan Januari-Desember 2015 dimulai dari penetapan kelompok tani pelaksana hingga evaluasi. Pemerintah memberikan paket bantuan dalam bentuk uang kepada kelompok tani pelaksana. Bantuan yang diberikan kepada kelompok tani berupa uang tunai sebesar Rp. 2.900 .000 yang kemudian dapat dicairkan untuk pembelian benih, pupuk urea, pupuk NPK, pupuk organik, pestisida, sosialisasi, dan bantuan tanam.

g. PAT dilaksanakan dengan pemberian paket bantuan saprodi kepada petani. POL dilakukan dengan pemberian pupuk organik dan pupuk berimbang. Selain itu terdapat pembuatan demplot dibeberapa lokasi strategis dengan tujuan untuk menggugah petani untuk mengadopsi inovasi dan teknologi baru yang dikembangkan oleh BPTP maupun perguruan tinggi. 
Pelaksanaan program UPSUS

PAJALE ini terdapat beberapa kendala seperti serangan tikus yang banyak menyebabkan kerugian pada petani karena tanamannya banyak dimakan dan dirusak sehingga akan menurunkan kuantitas dan kualitas hasil produksinya. Tikus merupakan hama yang paling sering merusak tanaman petani di berbagai daerah di DIY. Petani dan penyuluh pertanian telah berusaha penuh dalam memberantas tikus ini dengan gropyokan namun masih belum sepenuhya teratasi. Selain itu, ketersediaan air yang terbatas terutama pada wilayah Gunungkidul menjadi penghambat jalannya program ini. banyak petani yang mengeluhkan kurangnya air untuk tanaman mereka. Sehingga pemerintah melalui program ini memberikan bantuan pompa air guna membantu petani dalam memenuhi kebutuhan air dari tanaman yang dibudidayakan. Bantuan benih yang diberikan kepada petani terdapat kekurangan yaitu kualitas benihnya yang kurang baik. Benih-benih yang diberikan berkualitas rendah, banyak benih yang rusak, benih tidak tumbuh maupun kondisinya berjamur. Oelah karena itu, banyak petani yang sangat menyayangkan adanya hal tersebut.

Dari segi pendamping, mahasiswa juga mengalami kendala seperti waktu pelaksanaan pendampingan yang tergolong singkat sehingga masa pendampingan dirasa kurang oleh petani karena petani hanya mengalami pendampingan dalam satu musim tanam saja sehingga untuk musim tanam berikutnya petani sering merasa kesusahan untuk melaksanakan kegiatan seperti saat pendampingan berlangsung. Selain itu, pendamping sering berganti yang menjadikan perpindahan tugas sehingga pendampingan kurang maksimal karena pendamping pengganti belum paham bagaimana kondisi wilayah maupun petani secara keseluruhan.

\section{Persepsi Pendamping terhadap} Pelaksanaan Program UPSUS PAJALE

Persepsi pendamping paling baik terhadap peran BABINSA dalam pengawasan penyaluran bantuan benih, pupuk dan ALSITAN kepada petani $(81,50 \%)$. Menurut mahasiswa pendamping, BABINSA sebagai salah satu aparat negara yang menjunjung tinggi ketertiban aturan sehingga penyaluran bantuan tersebut hasrus benar-benar sampai pada petani sesuai dengan ketentuan yang ada. Namun sesuai dengen persepsi mereka sendiri, pendamping belum mampu mengembangkan model pemberdayaan petani di masyarakat (tingkat persepsinya 49,38\%), hal tersebut dikarenakan mahasiswa pendamping dapat dikatakan sebagai orang baru dalam lingkungan masyarakat, sehingga belum banyak mengetahui seluk beluk masyarakat secara mendalam. Ketiga pendamping tersebut mampu bekerja sama dengan baik dalam 
mendampingi petani pada setiap kegiatan yang ada, baik saat petani mengikuti kegiatan penyuluhan maupun pada saat petani melakukan kegiatan penerapan teknologi inovasi pada UPSUS PAJALE. Rata-rata tingkat persepsi pendamping terhadap kegiatan pendampingan UPSUS PAJALE mencapai 74,08\%.

Mahasiswa pendamping juga mempunyai persepsi terhadap berbagai kegiatan yang dilakukan oleh petani pada program ini. Penciptaan persepsi dilakukan dengan pengamatan langsung ke petani ketika mengikuti kegiatan penyuluhan dan petani melakukan penerepan teknologi inovasi dari UPSUS PAJALE. Mereka mengamati mulai dari keaktifan dari petani baik dari jumlah petani yang datang, maupun petani yang aktif bertanya atau menyampaikan pendapat ketika mengikuti jalannya penyuluhan. Berdasarkan persepsi dari pendamping, terdapat beberapa petani yang susah memahami materi yang disampaikan pada saat penyuluhan, hal tersebut dikarenakan umur petani tersebut yang sudah tua dan tidak produktif. Selain itu, mayoritas petani berpendidikan rendah (hanya lulus $\mathrm{SD} /$ SMP) sehingga lebih lambat menerima informasi yang disampaikan. Persepsi tersebut hanya mencapai $64,17 \%$. Akan tetapi, petani sangat antusias terhadap kegiatan yang dilakukan pada UPSUS PAJALE ini terutama pada kegiatan penggunaan benih unggul yaitu mencapai tingkat persepsi $82,50 \%$. Petani bersemangat dalam melakukan kegiatan tersebut karena hal itu menjadi motivasi terbesar dalam peningkatan produktivitas tanaman yang ditanam (baik padi, jagung dan kedelai). Penggunaan benih unggul ini menjadi modal awal petani untuk meningkatkan produktivitas tanamannya, sehingga nantinya produksi menjadi tinggi dan menaikkan pendapatan dari petani tersebut. Rata-rata tingkat persepsi pendamping terhadap kegiatan penyuluhan dan penerapan teknologi UPSUS PAJALE mencapai 76,26\%.

Persepsi pendamping terhadap pelaksanaan program UPSUS PAJALE dihitung dengan analisis uji proporsi, yang dijelaskan sebagai berikut:

a. Uji Statistik

$$
\begin{aligned}
& \mathrm{x}=23 \\
& \mathrm{n}=40 \\
& \mathrm{Po}=50 \% \\
& \mathrm{Zc}=\frac{\frac{x}{n}-p_{0}}{\frac{p_{0\left(1-P_{0}\right)}}{n}} \\
& \mathrm{Zc}=\frac{\frac{2 \varepsilon}{40}-50 \%}{\sqrt{\frac{50 \%(1-50 \%)}{40}}}=0,95
\end{aligned}
$$

b. Kesimpulan

$$
\begin{aligned}
& \mathrm{Zc}=0,95 \\
& \mathrm{Zt}=-1,640
\end{aligned}
$$

$\mathrm{Z}$ hitung $>\mathrm{Z}$ tabel :

Ho ditolak, Ha terima

Berdasarkan uji proporsi tersebut maka diketahui nilai $\mathrm{Z}$ tabel sebesar 
Tabel 1. Hasil Analisis Regresi Linear Berganda Mengenai Faktor-faktor yang Mempengaruhi Persepsi Pendamping Terhadap Pelaksanaan Program UPSUS PAJALE pada Model 5

\begin{tabular}{lcccc}
\hline \multicolumn{1}{c}{ Variabel } & $\begin{array}{c}\text { Koefisien Regresi } \\
(\mathrm{B})\end{array}$ & T Hitung & Sig & Ket \\
\hline Pengetahuan & 0,722 & 2,464 & 0,019 & $*$ \\
\hline Konstanta & 50,821 & & & \\
\hline R Square & 0,241 & & & \\
Ajusted R Square & 0,200 & & & \\
F Hitung & 5,887 & & & \\
F Tabel & 3,252 & & & \\
\hline
\end{tabular}

Keterangan : *signifikan pada taraf $5 \%$; NS: Non Significant

Sumber : Analisis Data Primer, 2016

-1,64 dan Zhitung sebesar 0,95. Zhitung lebih besar daripada Ztabel sehingga Ho ditolak dan Ha diterima. Hal tersebut menunjukkan lebih dari 50\% pendamping di DIY memiliki persepsi baik terhadap pelaksanaan program UPSUS PAJALE

Berdasarkan Tabel 1. dapat diketahui variabel yang berpengaruh signifikan terhadap persepsi pendamping adalah pengetahuan $\left(\mathrm{X}_{1}\right)$. Nilai signifikansi variabel pengetahuan 0,019 yang lebih kecil daripada taraf signifikansi $\alpha=0,05$. Hal tersebut menjelaskan bahwa variabel pengetahuan berpengaruh secara nyata pada persepsi pendamping terhadap pelaksanaan program UPSUS PAJALE.

Faktor yang Mempengaruhi Persepsi Pendamping terhadap Pelaksanaan Program UPSUS PAJALE

\section{Pengetahuan}

Pengetahuan merupakan hasil yang diperoleh setelah seseorang melakukan pengindraan terhadap suatu obyek. Berdasarkan penelitian yang dilakukan, dapat diketahui bahwa pengetahuan dari pendamping terhadap pelaksanaan program UPSUS PAJALE tergolong tinggi. Terdapat $60 \%$ pendamping mempunyai pengetahuan tinggi (tahu) terhadap pelaksanaan program ini dan $40 \%$ sangat mengetahui pelaksanaan UPSUS PAJALE. Berdasarkan hal tersebut, berarti hampir semua pendamping sudah mengetahui secara detail bagaimana pelaksanaan program UPSUS PAJALE di DIY.

Berdasarkan Tabel 1. diketahui koefisien regresi pada variabel pengetahuan sebesar 0,722 dan nilai signifikansi 0,019 yang lebih kecil daripada taraf signifikansi $\alpha=0,05$ sehingga diperoleh persamaan sebagai berikut:

$\mathrm{Y}=50,821+0,722 \mathrm{X}_{1}$

Keterangan :

$\mathrm{Y}=$ Persepsi Pendamping

$\mathrm{X}_{1}=$ Pengetahuan 
Berdasarkan penelitian yang dilakukan, variabel pengetahuan berpengaruh $(+)$ pada persepsi pendamping terhadap pelaksanaan program UPSUS PAJALE. Pengaruh positif pada koefisien regresi menunjukkan penambahan nilai variabel pengetahuan yang akan menaikkan persepsi pendamping. Semakin tinggi pengetahuan pendamping maka semakin baik pula persepsi pendamping terhadap pelaksanaan program UPSUS PAJALE di DIY. Nilai konstanta dari hasil persamaan regresi sebesar 50,821. Apabila tidak ada pengaruh variabel pengetahuan $(X=0)$, maka nilai persepsi sebesar 50,821. Nilai koefisien regresi variabel pengetahuan sebesar 0,722 yang menunjukkan setiap penambahan satu satuan variabel pengetahuan maka akan menaikkan persepsi pendamping sebesar 0,722 .

Pendamping memiliki pengetahuan yang paling tinggi mengenai manfaat penggunaan KATAM dan program GPPTT yaitu mencapai $84,50 \%$. Sedangkan indikator terendah yang didapatkan dari penelitian ini adalah pengetahuan pendamping tentang peran BABINSA dalam pelaksanaan UPSUS PAJALE. Indikator tersebut hanya memperoleh hasil $66,67 \%$ pendamping yang mengetahui peran tersebut, sehingga masih ada beberapa pendamping yang belum tahu tentang bagaimana peran BABINSA dalam UPSUS PAJALE. Mengatasi hal tersebut dapat dilakukan dengan penyuluhan dari penyelenggara UPSUS kepada pendamping, serta dapat dilakukan diskusi antar pendamping sehingga dapat saling mengetahui dan memahami tugas/peran dari masing-masing pendamping.

Faktor - Faktor yang Tidak Mempengaruhi Persepsi Pendamping Terhadap Pelaksanaan Program UPSUS PAJALE

Terdapat beberapa faktor internal dan eksternal yang tidak berpengaruh nyata pada persepsi pendamping terhadap pelaksanaan program UPSUS PAJALE di DIY. Faktor internal yang tidak mempengaruhi yaitu pengalaman dan minat bekerja di bidang pertanian. Faktor eksternal yang tidak mempengaruhi persepsi pendamping antara lain yaitu hubungan dengan petani, hubungan dengan Penyuluh Pertanian dan hubungan dengan BABINSA.

\section{Pengalaman}

Pengalaman adalah keseluruhan kegiatan intrakulikuler maupun ekstrakulikuler dari pendamping, yang dilakukan baik di dalam maupun di luar perkuliahan yang berkaitan dengan pendampingan pada petani. Berdasarkan penelitian yang dilakukan, dapat diketahui bahwa sebaran pengalaman dari pendamping tentang pendampingan pada petani tergolong kategori cukup (intensitas kadang-kadang). Hal ini yang 
berarti ada sebagian dari pendamping yang masih kadang-kadang melakukan pendampingan terhadap petani. Sebagian besar pendamping mendapatkankan pengalaman pendampingan pada petani diperoleh pada saat kegiatan intrakulikuler kampus yaitu dari kegiatan praktikum, magang/kerja lapangan maupun KKN. Oleh karena itu, tingkat pengalaman dari masing-masing pendamping tergolong sama (setara) sehingga menyebabkan tidak adanya perbedaan atau pengaruh terhadap penciptaan persepsi pendamping terhadap pelaksanaan program UPSUS PAJALE. Banyak atau sedikitnya pengalaman yang ada, tidak mempengaruhi bagaimana persepsi pendamping terhadap pelaksanaan program UPSUS PAJALE di DIY.

\section{Minat Bekerja di Bidang Pertanian}

Minat bekerja di bidang pertanian adalah bentuk keinginan dari pendamping terhadap berbagai pekerjaan yang berhubungan dengan bidang pertanian baik secara on farm maupun off farm. Berdasarkan penelitian ini, dapat diketahui bahwa sebaran minat bekerja dari pendamping pada dunia pertanian tergolong kategori sedang sehingga masih ada kemungkinan bahwa pendamping nantinya akan bekerja di luar bidang pertanian.

Mahasiswa pendamping memiliki minat bekerja paling banyak pada jenis pekerjaan di instansi pemerintah bidang pertanian sehingga pendamping ingin menjadi Pegawai Negeri Sipil (PNS) di Instansi Pemerintahan seperti Kementerian Pertanian, Dinas Pertanian dan lain sebagainya. Menurut pendamping, bekerja menjadi PNS merupakan pekerjaan yang ideal. Waktu yang diperlukan untuk bekerja tidak terlalu banyak dan hasil/gaji yang diperoleh juga lumayan banyak sehingga ini menjadi primadona dalam dunia kerja. Tingkat minat dari para pendamping tergolong sama, sebagian besar masih ragu-ragu untuk melanjukan kerja di bidang pertanian atau beralih ke bidang yang lain. Sehingga minat bekerja tidak mempengaruhi persepsi pendamping terhadap pelaksanaan program UPSUS PAJALE di DIY.

\section{Hubungan dengan Petani}

Hubungan dengan petani adalah segala bentuk interaksi yang dilakukan oleh pendamping program UPSUS PAJALE yang dilakukan dengan petani terutama yang terlibat dalam kegiatan/program ini. Berdasarkan penelitian yang dilakukan, hubungan pendamping dengan petani terjadi secara kadang-kadang. Interaksi yang paling sering terjadi ialah ketika dilakukannya pertemuan kelompok dalam kegiatan penyuluhan UPSUS PAJALE. Pada saat tersebut terjadi komunikasi yang hanya berkaitan dengan materi penyuluhan sehingga interaksi yang ada terjadi karena hanya ingin memberikan informasi 
misalnya cara budidaya, pemupukan dan lain-lain, sehingga tidak mempengaruhi bagaimana persepsi pendamping terhadap pelaksanaan program UPSUS PAJALE. Tinggi rendahnya dari intensitas hubungan tersebut, tidak mempengaruhi persepsi pendamping terhadap pelaksanaan program UPSUS PAJALE.

\section{Hubungan dengan Penyuluh Pertanian}

Hubungan dengan Penyuluh Pertanian adalah segala bentuk interaksi yang dilaksanakan oleh pendamping dengan Penyuluh Pertanian dalam membicarakan informasi terkait pelaksanaan program UPSUS PAJALE. Berdasarkan penelitian ini, pendamping sering berhubungan dengan Penyuluh Pertanian secara informal. Hal tersebut berarti bahwa sebagian besar pandamping berhubungan dengan Penyuluh Pertanian pada saat diluar kegiatan penyuluhan atau penerapan teknologi. Interaksi pendamping dengan Penyuluh Pertanian terjadi ketika berada di BP3K. Komunikasi tersebut berkaitan dengan latar belakang dari mahasiswa pendamping ataupun Penyuluh Pertanian sehingga tidak mempengaruhi bagaimana persepsi terhadap pelaksanaan UPSUS PAJALE. Oleh karena itu, tinggi rendahnya intensitas hubungan yang terjalin, tidak mempengaruhi persepsi pendamping terhadap pelaksanaan program UPSUS PAJALE di DIY.

\section{Hubungan dengan BABINSA}

Hubungan dengan BABINSA adalah segala bentuk interaksi yang dilaksanakan oleh pendamping dengan BABINSA selaku pendamping program UPSUS PAJALE dalam mengkomunikasikan pelaksaan kegiatan tersebut. Hubungan yang terjalin antara pendamping dengan BABINSA terjadi secara kadang-kadang. Biasanya hubungan tersebut terjalin ketika petani melakukan penerapan teknologi. Pada saat itu, BABINSA selaku pengawas banyak memperhatikan kegiatan yang dilakukan, mahasiswa pendamping ikut mendampingi petani. Komunikasi yang terjalin hanya sebatas pertukaran informasi pelaksanaan pengawasan dan pengawalan yang dilakukan oleh BABINSA sehingga belum bisa mencakup gambaran pelaksanaan program secara utuh sehingga hubungan pendamping dengan BABINSA tidak berpengaruh dalam penciptaan persepsi terhadap pelaksanaan program UPSUS PAJALE secara utuh. Oleh karena itu, tinggi rendahnya intensitas hubungan yang terjalin, tidak mempengaruhi persepsi pendamping terhadap pelaksanaan program UPSUS PAJALE di DIY.

\section{KESIMPULAN DAN SARAN}

\section{Kesimpulan}

1. Pelaksanaan program UPSUS PAJALE tahun 2015 di DIY meliputi kegiatan RIJT, bantuan ALSINTAN, benih dan pupuk, pengaturan musim tanam serta 
kegiatan GP-PTT dapat berjalan dengan baik. Namun petani masih belum mampu mengoperasikan ALSINTAN dengan benar.

2. Sesuai dengan hasil penelitian yang telah dilakukan, 57,50\% pendamping memiliki persepsi yang baik terhadap pelaksanaan program UPSUS PAJALE di DIY, baik dalam kegiatan pendampingan maupun kegiatan penyuluhan serta penerapan teknologi yang dilakukan oleh petani. Tingkat persepsinya mencapai $75,17 \%$. Indikator terendah ialah persepsi pada peran mahasiswa pendamping dalam memberdayakan petani $(49,38 \%)$ dan persepsi pada pemahaman petani pada materi penyuluhan $(64,17 \%)$.

3. Faktor yang berpengaruh nyata pada persepsi pendamping terhadap pelaksanaan program UPSUS PAJALE di DIY adalah pengetahuan $\left(0,722 \mathrm{X}_{1}\right)$. Semakin tinggi pengetahuan, maka semakin baik persepsi pendamping terhadap pelaksanaan program UPSUS PAJALE. Indikator pengetahuan yang terendah ialah pengetahuan tentang peran BABINSA $(66,67 \%)$ dan pengetahuan indikatoryang tertinggi ialah pengetahuan terkait manfaat penggunaan KATAM dan kegiatan GP-PTT (84,50\%).

4. Kendala utama pada pelaksanaan program UPSUS PAJALE di DIY adalah serangan OPT tikus, kesusahan air sehingga banyak terjadi kekeringan, serta kualitas bantuan benih rendah.

\section{Saran}

1. Untuk meningkatkan kemampuan petani dalam mengoperasikan ALSINTAN, dapat dilakukan dengan pelatihan tentang cara penggunaan ALSINTAN sesuai dengan prosedur.

2. Persepsi pendamping terhadap pelaksanaan program UPSUS PAJALE tergolong baik, namun terdapat beberapa persepsi yang masih kurang baik yaitu persepsi terhadap pemberdayaan petani dan persepsi terhadap pemahaman petani pada materi penyuluhan. Maka dari itu, perlu diadakan sosialisasi yang lebih intensif kepada petani agar petani lebih paham tentang materi yang disampaikan. Pemberdayaan petani dapat ditingkatkan dengan menaikkan tingkat partisipasi petani dalam berbagai kegiatan sehingga petani tidak hanya sebagai sasaran program (pasif).

3. Faktor yang berpengaruh pada persepsi pendamping terhadap pelaksanaan program UPSUS PAJALE di DIY yaitu pengetahuan. Akan tetapi terdapat peran yang belum diketahui seperti peran dari BABINSA. Oleh sebab itu, penyelenggara UPSUS perlu mengadakan penyuluhan tentang kegiatan pendampingan serta diadakannya diskusi bersama antara Penyuluh Pertanian, BABINSA dan mahasiswa sehingga para pendamping lebih tahu bagaimana peran masingmasing pendamping tersebut yang sesuai dengan tupoksinya. 
4. Untuk mengatasi serangan tikus dapat dilakukan dengan pengendalian hama secara mekanis maupun kimia. Sedangkan permasalahan kurangnya air dapat diatasi dengan pengadaan pompa air maupun pergiliran penggunaan air. Selain itu, bantuan yang diberikan seharusnya diteliti terlebih dahulu sehingga kualitasnya terjaga dengan baik sampai bantuan diterima dan digunakan oleh petani atau bisa dengan menggunakan benih bersertifikat.

\section{DAFTAR PUSTAKA}

Batuadji, K., dkk. 2009. Hubungan Antara Efektivitas Fungsi Bimbingan dan Konseling Dengan Persepsi Siswa Terhadap Bimbingan dan Konseling di Sekolah Menengah Pertama Stella Duce I Yogyakarta. Jurnal Psikologi $36(1): 18-34$

Bilondatu, M.R., dkk. 2013. Motivasi, Persepsi, Dan Kepercayaan Pengaruhnya Terhadap Keputusan Pembelian Konsumen Pada Sepeda Motor Yamaha Di Minahasa. Jurnal EMBA 1(3) : 710-720

BPPSDM Pertanian. 2015. Modul Pendampingan Mahasiswa Dalam UPSUS PAJALE. Badan Penyuluhan dan Pengembangan Sumber Daya Manusia Pertanian. Kementerian Pertanian. Jakarta.
Fitria, A., dkk. 2013. Persepsi Siswa Tentang Perilaku Seksual Remaja Dan Implikasinya Terhadap Pelayanan Bimbingan Dan Konseling. Jurnal Ilmiah Konseling 2 (1) : 202-207

Indraningsih, K.C. 2015. Implementasi dan Dampak Penerapan Legislasi Penyuluhan Pertanian terhadap Capaian Swasembada Pangan. Jurnal Analisis Kebijakan Pertanian 13 (2) : 109-128.

Rudyanto, M. 2015. Persepsi anggota terhadap peran kelompok tani dalam penerapan teknologi usahatani bawang merah di Kabupaten Bantul [skripsi]. Yogyakarta : Fakultas Pertanian. Universitas Gadjah Mada.

Sadono, D. 2008. Pemberdayaan Petani : Paradigma Baru Penyuluhan Pertanian di Indonesia. Jurnal Penyuluhan 4 (1) : 65-74.

Saputro, R dan Prof. Hatane Semuel. 2013. Analisa Pengaruh Motivasi, Persepsi, Sikap Konsumen Terhadap Keputusan Pembelian Mobil Daihatsu Xenia di Sidoarjo. Jurnal Manajemen Pemasaran 1 (1): 1-12.

Surakhmad, W, 1990, Pengantar Penelitian Ilmiah dan Dasar Metode Teknik. Transito, Bandung. 